\title{
VÝVOJ HISTORICKÉ ZÁSTAVBY PARCELY Č. 1149/3 P̌̌I KOPEČNÉ ULICI V BRNĚ
}

\author{
ANTONÍN ZŮBEK
}

\begin{abstract}
Abstrakt: Př́spěvek shrnuje výsledky záchranného archeologického výzkumu parcely č. 1149/3 při Kopečné ulici v Brně, který se realizoval v letech 2013 a 2014. Na základě jeho výsledků se zde podařilo archeologické situace rozčlenit do šesti základnich fází, které reprezentuji stavebni vývoj parcely od 13. do 20. století. Parcela byla součásti předměstské osady, jejiž obyvatelé byli ve středověku označováni v písemných pramenech jako ,chudi pod Puhlikem“.
\end{abstract}

Klićová slova: středověk - novověk - Brno - predměstí-zástavba.

\section{The Historical Development of Plot no. 1149/3 by Kopečná Street, Brno}

Abstract: This paper sums up the results of rescue archaeological research into plot no. 1149/3 by Kopečná Street, Brno conducted in 2013 and 2014. On the basis of its results it was possible to divide the archaeological contexts into six phases that represent the building development of the plot between the 13th century and the 20th century. The plot was part of a suburban settlement whose inhabitants were referred to in medieval written sources as "the poor below Puhlik Hill".

Key words: Middle Ages - modern age - Brno - suburb - constructions.

\section{Historický úvod}

Parcela č. 1149/3 dnes náleží ke katastrálnímu území Staré Brno. Je součástí domovního bloku, který je sevřen ulicemi Kopečná a Studánka. Parcela je vázána na východní linii Kopečné ulice v její střední části. Místo se nachází při západním úpatí skalního ostrohu Petrova a na mírně vyznívající partii svahu, který se táhne od Pekařské ulice směrem k jihu k někdejšímu Svrateckému náhonu (dnes Vodní ulice).

Již v období stř̌edověku bylo území zapojeno do sídelní struktury, která se utvářela v nejbližším okolí královského města Brna (ke vzniku a nejstarší historii města obecně naposledy 2. svazek Dějin Brna - viz Jan ed. 2013). Tvořila ji předměstí, která spadala pod jurisdikci města, a několik dalších osad a sídel, která měla rozličný status. Vlastní předměstí utvářela víceméně souvislý prstenec, který bezprostředně obepínal obvod města vymezený fortifikačním pásem. Rozvíjela se v podstatě souběžně s vnitřním městem již od první poloviny 13 . století. V některých případech lze uvažovat o zapojení starších (předlokačních) osad. Struktura a územní rozsah historických předměstí se z velké části stabilizovaly ve 14 . století. Patnácté století znamenalo útlum vývoje. $\mathrm{V}$ důsledku husitských a pak česko-uherských válek došlo k výraznému poškození předměstí a redukci zástavby. Negativně působila špatná ekonomická situace. V průběhu 16. století sice nastával postupně nový rozvoj předměstí, ten ovšem nedosáhl předhusitské úrovně. Do poloviny 17. století pak bylo pro předměstské osídlení nepříznivé zesilování městského opevnění, avšak naprostou katastrofu představovalo dvojí švédské obléhání v letech 1643 a 1645 a následná přeměna Brna na barokní pevnost. Již před prvním švédským obléháním roku 1643 dalo samo město vypálit a strhnout budovy, které by ztěžovaly přehled obránců a umožňovaly Švédům snazší a krytý př́ístup. Ještě citelnější byly přípravy na druhé švédské obléhání roku 1645. Vlastní obléhání a vojenské akce pak toto katastrofální postižení předměstí dovršily. Některé části předměstského osídlení zanikly definitivně, struktura jiných se zřejmě značně změnila. K výrazné přeměně došlo s výstavbou ,průmyslového“ Brna v 19. století a budováním „,velkého“ Brna ve 20. století (ke středověké struktuře předměstí stále Vičar 1966, podle něj nověji Procházka-Kolařík-Zůbek 2013, 568-600; základní historický přehled Kuča 2000).

Podle rejstříku městské sbírky z roku 1343 se osídlení na předměstích dělilo obdobně jako vnitřní část města do čtyř čtvrtí. Nejblíže parcele č. 1149/3 se nacházela čtvrtá čtvrt' (Quartum quartale extra civitatem), a to její část zvaná ,před branou Brněnskou“ (ante portam Brunnensem). 
Její obyvatelé osídlili horní části Pekařské ulice a prostor dnešního Šilingrova náměstí. Pekařská ulice spojovala město od vyústění z Brněnské brány s osídlením na Starém Brně. To ve středověku představovalo obtížně zařaditelný útvar s vlastním rychtářem a blížilo se postavení městečka (Flodrová-Müller 2007; Procházka-Kolařík-Zůbek 2013, 558-568). Ve své stř̌ední části probíhala Pekařská ulice ze severní strany kolem osídlení na Provaznickém vršku (Lochenbergu - dnes přibližně Kopečná 43), které bylo označováno jako Statek kostela Všech svatých. Pozemky tohoto sídelního útvaru byly západním sousedem území, jehož součástí je i parcela č. 1149/3. Tímto prostorem procházela od středověku komunikace, která se pod východním úpatím Provaznického vršku odkláněla od Pekařské ulice a přibližně v průběhu dnešní Kopečné ulice směřovala ke Svrateckému náhonu. Za ním se nacházela ves Novosady, která ležela v bezprostředním jihozápadním sousedství města. Podél náhonu bylo možné se dostat k Židovské bráně (dnes ústí Masarykovy), kterou se město otevíralo směrem k jihu. Lze předpokládat, že osídlení v místech okolo parcely č. 1149/3 bylo vázáno právě na jmenovanou komunikaci. V 18. století je označována jako Malá Pekařská (Kleine Bäckergasse), nynější název se objevil až v roce 1867 v německé podobě Berggasse. Český ekvivalent přišel až s rokem 1918 (Flodrová 1997, 119). Do tohoto prostoru lze umístit př́bytky specifické skupiny obyvatel předměstí, která je označována v písemných pramenech jako „chudí pod Puhlíkem“. Termínem „Puhlík“ se ve středověku rozuměl výběžek Petrova v místě dnešních Denisových sadů (dříve také Františkov). V berním rejstř́ku z roku 1348 jsou „chudí pod Puhlíkem“ uvedeni neúplně jako poslední skupina poplatníků hned za poplatníky z předměstské části „před branou Brněnskou“. Rejstř́k z roku 1365 uvádí asi 21 domků chudiny, dělníků, nosičů apod. (Procházka-Kolařík-Zůbek 2013, 597; Vičar 1966, 234).

Podobu středověké a novověké zástavby tohoto předměstí neznáme. Na obrazu H. B. Beyera a H. J. Zeisera z poloviny 17. století není žádná zaznamenána. Obraz dokumentující švédské obléhání města v roce 1645 přitom poměrně velice přesně a věrohodně zachycuje podobu města a jeho okolí (uložen ve sbírkách Muzea města Brna pod inventárním číslem 2284). Stejnou situaci zaznamenávají také další, už méně přesná vyobrazení ze stejné doby - mědirytina Merianova (součást knihy Merian 1650) a anonymní plán ze spisu Relatione dell assedio di Bruna e de la fortezza di Spilberg (v seznamu pramenů pod Relatione). Zástavbu zobrazuje až Folpert van Ouden Allen asi okolo roku 1690 (uloženo ve sbírkách Muzea města Brna). Otázkou je ovšem věrohodnost a přesnost jeho obrazu. První plány zaznamenávající zástavbu podél Kopečné ulice pocházejí ze závěru 18. století a počátku 19. století. Zachycují parcelu č. 1149/3 jako součást domovního bloku sevřeného mezi dvěma ulicemi (dnes označován jako blok 61). Je možné rozeznat, že blok sestává ze šesti až sedmi domovních jednotek. Parcela č. 1149/3 tvořila tehdy jeden majetkový celek s dnešní parcelou č. 1149/1. Dům, který zde stával, tvořil jižní ukončení domovního bloku 61. Po zavedení popisných čísel v roce 1770 byl nejprve označen číslem 99 v katastrální obci Velká a Malá Pekařská ulice. Později nesl číslo 94. Při zavedení orientačních čísel v roce 1867 byl označen v Kopečné ulici čísly 38 a 40, v ulici Studánka čísly 1 a 3 . Všechny díly však měly stejného majitele.

Nejstarší dohledatelná zpráva o domě pochází z poloviny 18. století. Dle smlouvy ze 16. prosince 1757 dostala dům „na Dolní Pekařské“ Eva Pollerová od svého manžela Šimona Pollera. Ve smlouvě je dům označen jako nárožní (Archiv města Brna, fond A 1/3, rkp. č. 1912, fol. 199). Dne 1. dubna 1803 sepsali zednický mistr Josef Zeissl a tesař Vencl Eitelberger odhad domu. Odhadní cenu stanovili na 7100 zlatých. Dům popsali tak, že ze tř́i stran stojí volně, je patrový a podsklepený v rozsahu dvou sklepů na 30 sudů vína. Na dvoře o výměře 35 čtverečních sáhů měl studnu. Dům byl postaven z dobrého materiálu. Krov vykazoval „střední stav“, střechu pokrýval šindel. Dle popisu šlo o dům rozlehlý, s patrovými dvorními kř́ílly. Dispozice se popisuje následovně: V přízemí se nacházela klenutá předsíň dlážděná cihlami (průjezd?). Nalevo byla klenutá místnost a k ní přináležející klenutá kuchyně. Dispozice „napravo“ byla shodná. „Napravo ve dvoře na straně Kalvárie“ (rozumí se svah Františkova s kř́žzovou cestou) se nacházela rovněž klenutá místnost se zcela klenutou kuchyní, dále nad ní tři místnosti a tři kuchyně. Za těmito místnostmi v poněkud vyvýšené postranní budově byly tři pokoje s kuchyněmi. Nalevo proti ulici (míněna snad ulice Studánka) byly dvě místnosti se zvláštním vchodem a dvě kuchyně a ve stejném traktu 


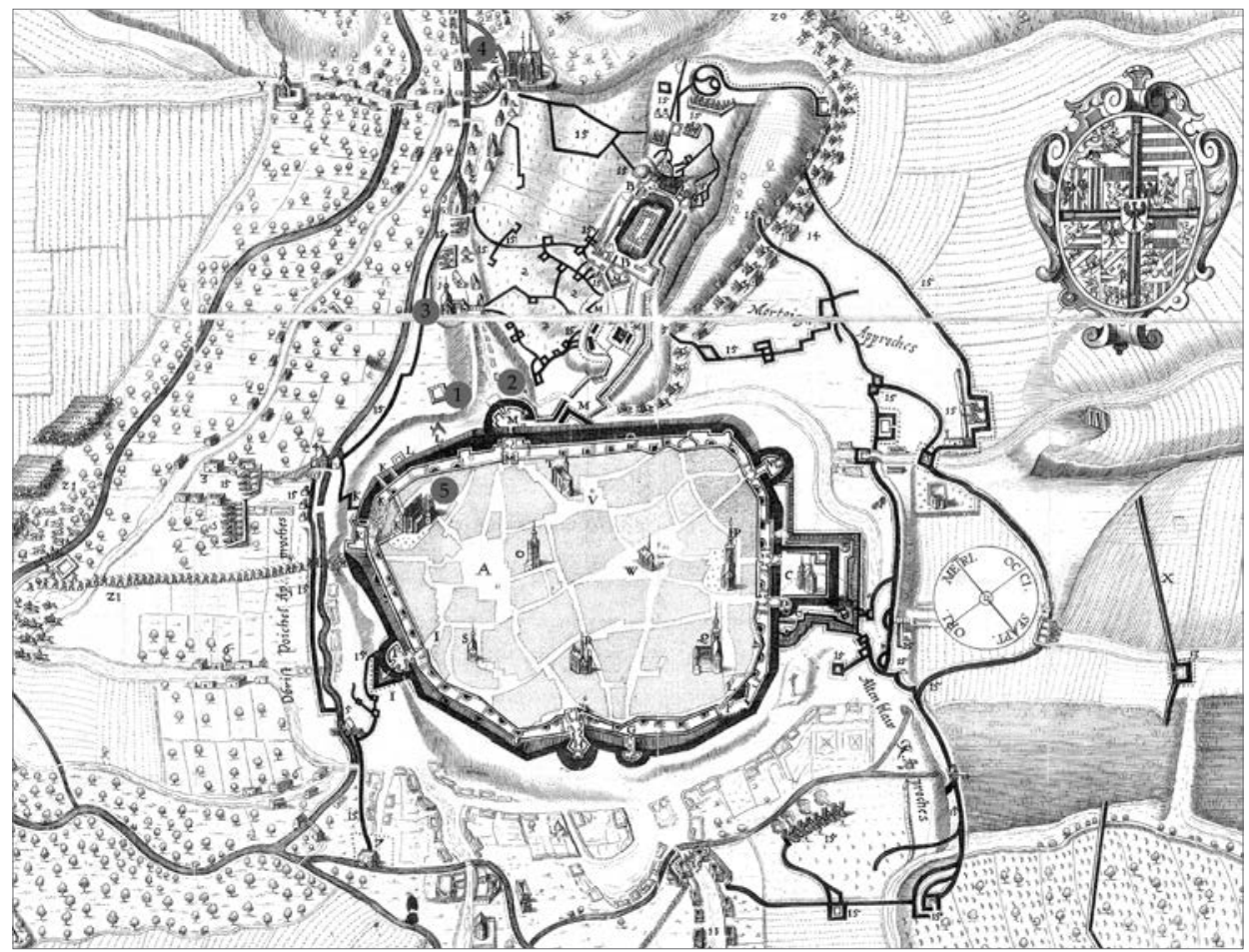

Obr. 1. Výřez z plánu ze spisu Relatione dell assedio di Bruna e de la fortezza di Spilberg (Vienna, 1672). Zobrazuje švédské obležení města v roce 1645. Zachycena je i struktura předměstského osídlení. Plán je orientován horním okrajem k západu. Čísla v šedých kroužcích označují polohu v textu zmiňovaných míst: 1 - prostor pod Puhlíkem; 2 - osídlení před Brněnskou branou; 3 - Provaznický vršek; 4 - Staré Brno; 5 - Petrov.

Abb. 1. Ausschnitt eines Plans aus der Schrift Relatione dell assedio di Bruna e de la fortezza di Spilberg (Vienna, 1672). Darstellung der schwedischen Belagerung der Stadt im Jahr 1645. Wiedergegeben wird auch die Struktur der Besiedelung der Vorstadt. Der obere Rand des Plans ist nach Westen ausgerichtet. Die Ziffern in den grauen Kreisen kennzeichnen die Lage der im Text erwähnten Stellen: 1 - Raum unterhalb des Purzelbüchel; 2 - Besiedelung vor dem Brünner Tor; 3 - Lochenberg; 4 - Alt-Brünn; 5 - Petersberg.

ještě jedna místnost a „výše“ tři pokoje s kuchyněmi. V prvním patře proti ulici nad hlavním vchodem se nacházelo klenuté schodiště, předsíň a nalevo i napravo vždy jeden pokoj s kuchyní, dále pak jedna komora. Proti ulici Malá Pekařská (tj. Kopečná) byla v tomto patře předsíň a dva pokoje s kuchyněmi (Archiv města Brna, fond A 1/3, rkp. č. 1914, fol. 11n.).

Přinejmenším od 40. let 19. století fungovala v domě pekárna. Hospodařil zde pekař Alois Stepke, který dne 22. června 1866 žádal městský stavební úřad o povolení ke stavbě druhé chlebové pece, protože hodlal dodávat chléb i pro vojsko. Pec měla být umístěna v místnosti do ulice na levé straně a k odvodu kouře měl sloužit komín přilehlé klenuté kuchyně. Dne 29. února 1868 žádal o povolení vystavět nové záchody ve dvoře a vyměnit dřevěnou pavlač v prvním patře za konstrukci se železnými nosníky (Archiv města Brna, fond A 1/33, inv. č. 718, kart. 175). Přinejmenším od roku 1882 dům vlastnil pekař Karel Maiwald s manželkou Karolínou. Dne 14. března 1882 žádal o povolení ke stavbě dvou nových pekařských pecí v pravém dvorním křídle za účelem „rozšíření podniku“. Dne 14. dubna 1883 žádal Maiwald o povolení k úpravě okna jako vstupu do krámu v části domu Kopečná 38 / Studánka 1. Pravděpodobně šlo o vstup, který je patrný na historických fotografiích domu z počátku 20. století. Poslední úpravy prováděl na jaře 1887 , kdy nechal opravit a přestavět pekařskou pec. Za tím účelem byly v domě, neznámo přesně kde, sneseny čtyři příčky a vybourán strop, zazděno bylo okno v krámě. Nejstarší historii domu stručně zpracoval PhDr. Pavel Borský, CSc. Jeho rukopis je v upravené podobě součástí nálezové zprávy z archeologického výzkumu (Černá-Zůbek 2015). 
V současné době je někdejší dům č. 94 rozdělen na dvě majetkové jednotky. Na jižní parcele č. 1149/1 se zachoval historický nárožní dům Kopečná č. 319/38, zástavba severní parcely č. 1149/3 (dům Kopečná č. 1001/40) byla snesena a pozemek byl po jistou dobu nezastavěn (obr. 2 a 3 ). V roce 2014 došlo k vybudování novostavby bytového domu v podstatě na celém půdoryse parcely.

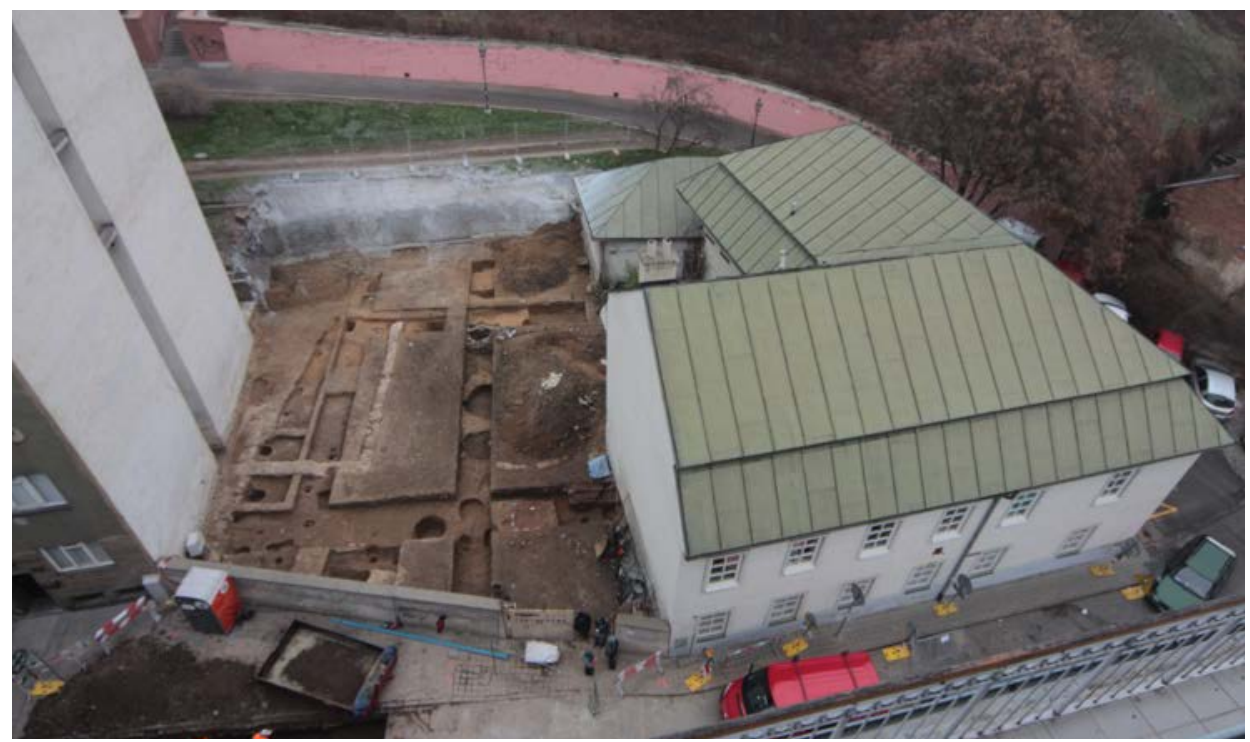

Obr. 2. Pohled od západu na parcelu č. 1149/3 v průběhu archeologického výzkumu v roce 2013. Na vedlejší parcele 1149/1 stávající dům č. 319/38. Zdroj fotoarchiv Archaia Brno, o. p. s. - foto č. 19051-2013.

Abb. 2. Blick von Westen auf Parzelle Nr. 1149/3 während der archäologischen Grabung im Jahr 2013. Auf der Nachbarparzelle 1149/1 stehendes Haus Nr. 319/38. Quelle Fotoarchiv Archaia Brno, o. p. s. - Foto Nr. 19051-2013.

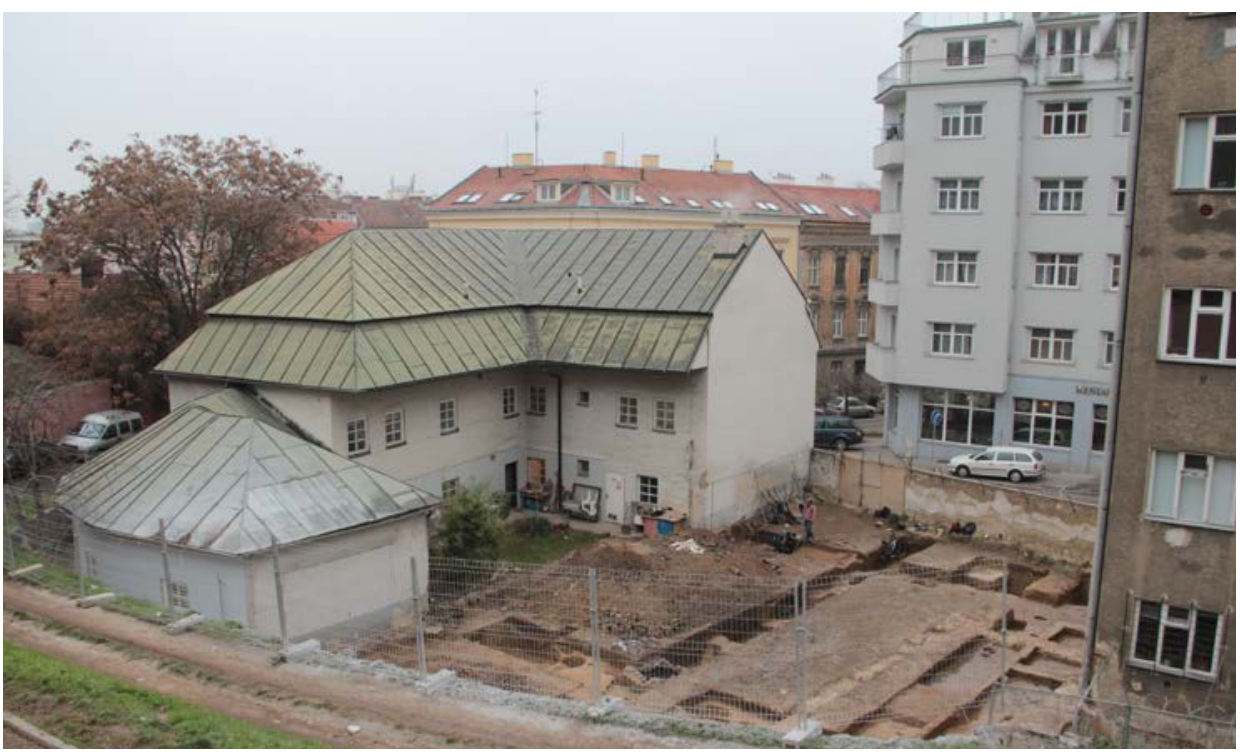

Obr. 3. Pohled od severovýchodu na parcelu č. 1149/3 v průběhu archeologického výzkumu v roce 2013. Na vedlejší parcele 1149/1 stávající dủm č. 319/38. Zdroj fotoarchiv Archaia Brno, o. p. s. - foto č. 19128-2013.

Abb. 3. Blick von Nordosten auf Parzelle Nr. 1149/3 während der Grabung von 2013. Auf der Nachbarparzelle 1149/1 stehendes Haus Nr. 319/38. Quelle Fotoarchiv Archaia Brno, o. p. s. - Foto Nr. 19128-2013. 


\section{Archeologický výzkum}

Parcela č. 1149/3 má dnes přibližně obdélný půdorys o rozměrech $28,5 \times 15,5 \mathrm{~m}$. Kratší stranou je na západě vázána na východní linii Kopečné ulice. Delší osou se zařezává do svahu, který stoupá východním směrem k Petrovu. Z východní strany obchází parcelu ulice Studánka. Prostor parcely byl již před výstavbou bytového domu plochý a rovný. Výška stěny „seřizlého“ svahu při východní hranici parcely činila $3 \mathrm{~m}$.

Poznatky o historickém vývoji zástavby parcely byly získány především při záchranném archeologickém výzkumu, který byl vyvolán výstavbou zmíněného bytového domu. Na přelomu let 2013 a 2014 ho realizovala společnost Archaia Brno, o. p. s., na základě smlouvy, kterou uzavřela s investorem stavby Statutárním městem Brnem, městskou částí Brno-střed (akce č. A37/2013 - Černá-Zůbek 2015). Předmětné parcely se v minulosti ještě dotk1 výzkum z roku 2004, který souvisel s projektem Sanace brněnského podzemí bloku 61. V jeho rámci byly na parcele položeny tři zjištovací sondy malého rozsahu (akce č. A62/2004 - Zapletalová 2005). Výsledky tohoto výzkumu byly v podstatě překonány informacemi získanými při akci z let 2013 a 2014. V nejbližším okolí parcely se již realizovala celá řada archeologických počinů rozmanitého charakteru. Věnovat se jejich výsledkům není náplní předkládané práce. Za daného stavu ostatně nemá valného smyslu o nich referovat. Tato skutečnost je jasně patrná již z některých dílčích předběžných souhrnů (napřr. Procházka 2000, 92, 95; Procházka-Kolařík-Zůbek 2013, 597-598). Velká část výzkumů nebyla plně vyhodnocena a některé jsou ještě stále ve fázi zpracování. Celkové zhodnocení jejich informačního př́nosu k rekonstrukci historického vývoje zdejšího osídlení bude úkolem chystané samostatné studie. K ní ovšem povede cesta přes pečlivý rozbor jednotlivých výzkumů. K publikačnímu výstupu je v nejbližší době připravován stavební vývoj parcely někdejšího domu Kopečná 24.

Po odtěžení recentních navážek (mocnost ca $0,5 \mathrm{~m}$ ) byl výzkum v místech plánovaných zemních zásahů stavby prováděn metodou plošné exkavace. Šlo většinou o základové pasy a technické šachty. Exkavace byla $\mathrm{v}$ případě hlubších archeologických situací (odpadních jímek, studny apod.) zastavena na požadované základové spáře stavby (v průměru se pohybovala v hloubce $1 \mathrm{~m}$ od snížené úrovně). Později došlo ke změně technologie založení budovy, většina terénu byla proto snížena v průměru o $0,7 \mathrm{~m}$. Toto snižování bylo prováděno stavební firmou pouze za dohledu archeologa. V jižní části došlo k začištění a dokumentaci snížené úrovně, v západní se snižování odehrálo především v rámci výplní zahloubené partie stavby s. s. j. 045, část severní a východní byla již kompletně prozkoumána v předchozí etapě. Blok ve stř̌ední části zůstal archeologicky téměř nedotčen (obr. 4).

Archeologické situace byly na parcele tvořeny výhradně výplněmi výkopových aktivit a relikty základových partií zděných konstrukcí. Zahloubeny byly do geologického podloží. V odtěžené části terénu ho tvořily především sprašové hlíny. Na východním profilu v zářezu do svahu byly dokumentovány také bloky jílu (téglu) a štěrkové vrstvy. Skladba a podmínky uložení vrstev napovídaly o jejich možných posunech v důsledku pohybů na svažitém terénu.

Př́tomné situace byly výsledkem aktivit, které se na parcele odehrávaly od 13. do 20. století. Starší osídlení nebylo doloženo. Zcela jej vyloučit ovšem nelze. Jeho stopy mohly být „smazány“ následnou činností. Datování situací bylo provedeno na základě mobiliáře odebraného z jednotlivých uloženin. Soubory byly spíše nevýrazné a často také málo početné. Archeologickým výzkumem byla získána nálezová kolekce čítající na 6500 položek. Největší podíl tvoří zlomky keramických nádob. Dále byly zastoupeny zvířecí kosti, zlomky skleněných nádob a fragmenty železných předmětů. V malém počtu byly získány předměty z barevných kovů (např. mince).

\section{Stavební vývoj}

Archeologické situace se podařilo rozčlenit do šesti základních skupin (fází), které reprezentují stavební vývoj parcely. 


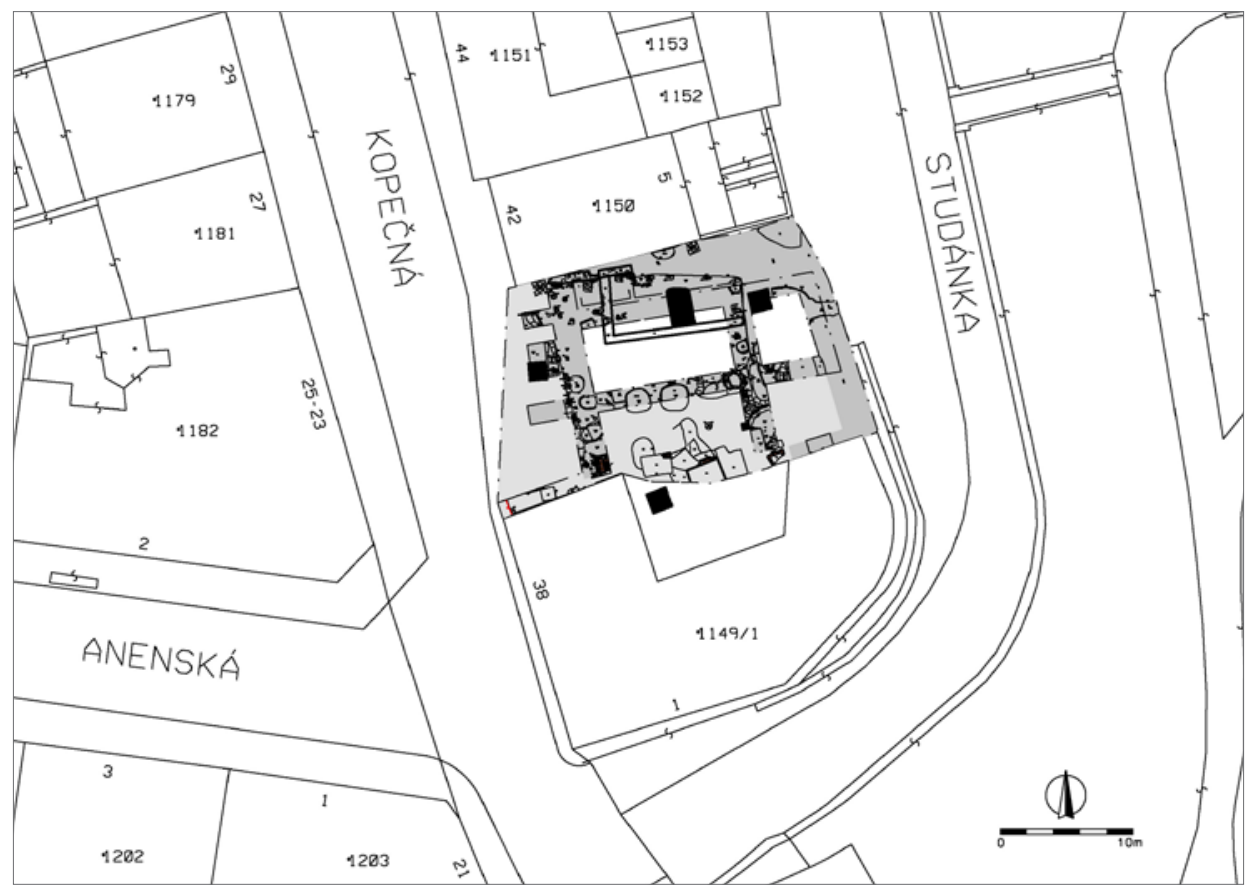

Obr. 4. Parcela č. 1149/3 a její nejbližší okolí. Tmavě šedá - plochy zkoumané metodou plošné exkavace; světle šedá - plochy dohledované a zkoumané během zemních prací stavby; bílá - archeologický terén nebyl exkavován; černá - sondy z roku 2004.

Abb. 4. Parzelle Nr. 1149/3 und ihre nächste Umgebung. Dunkelgrau - durch großflächige Aushebung untersuchte Fläche; hellgrau - während den Erdarbeiten des Baus untersuchte Flächen; weiß - das archäologische Gelände wurde nicht ausgehoben; schwarz - Sondierschnitte aus dem Jahr 2004.

\section{1. fáze stavebního vývoje (13. století)}

Stratigraficky nejstarší ze zkoumaných situací byly zahloubené aktivity s. s. j. 019, 020, 028 a 046. ${ }^{1}$ U prvních dvou jmenovaných šlo o jámy neznámé funkce, které spolu zřejmě souvisely. Není zcela vyloučena jejich př́íslušnost k následující stavbě s. s. j. 026, byly by zahloubeny do jejího dna. Aktivita s. s. j. 046 představuje relikt zahloubené části stavby. Půdorys zůstal neznámý $(>7 \times>6,8 \mathrm{~m})$. Dokumentovány byly pouze segmenty východní stěny a části dna. Zaznamenaná hloubka činila $1,10 \mathrm{~m}$. Konstrukce stěn zahloubené části stavby byla tvořena zřejmě dřevěnými prvky. Př́islušná stavba stávala $\mathrm{v}$ čele parcely. Pokud bychom v této době počítali se stejnou šiř́kou parcely, pravděpodobně by šlo o dům okapově orientovaný směrem ke komunikaci. Měl by blíže neurčený přesah za stávající domovní linii Kopečné ulice. Uvažovat lze ovšem také o menší stavbě, a tudíž o parcele menší šířky. V tomto směru je nutné připomenout, že aktivity této stavební fáze byly registrovány pouze v jihozápadní čtvrtině stávajícího pozemku. Zcela hypotetickou zůstává možnost, že byly zachyceny situace v severní části parcely, která zasahovala dále na jih (na dnes sousední parcelu č. 1149/1). Objekt s. s. j. 028 (jáma neznámé funkce) zřejmě souvisel s provozem zázemí parcely. Nacházel se ve vzdálenosti 11 m od stávající uliční linie. Je možné, že parcela nebyla v tomto období zaříznuta do svahu tak hluboko (obr. 5).

1 S. s. j. - svazek stratigrafických jednotek. Podle užité metodiky zahrnuje jeden svazek aktivity, které spolu souvisejí a často vytvářejí vyšší celek. Pro jednotlivé aktivity se užívá termín stratigrafická jednotka (zkratka s. j.). 


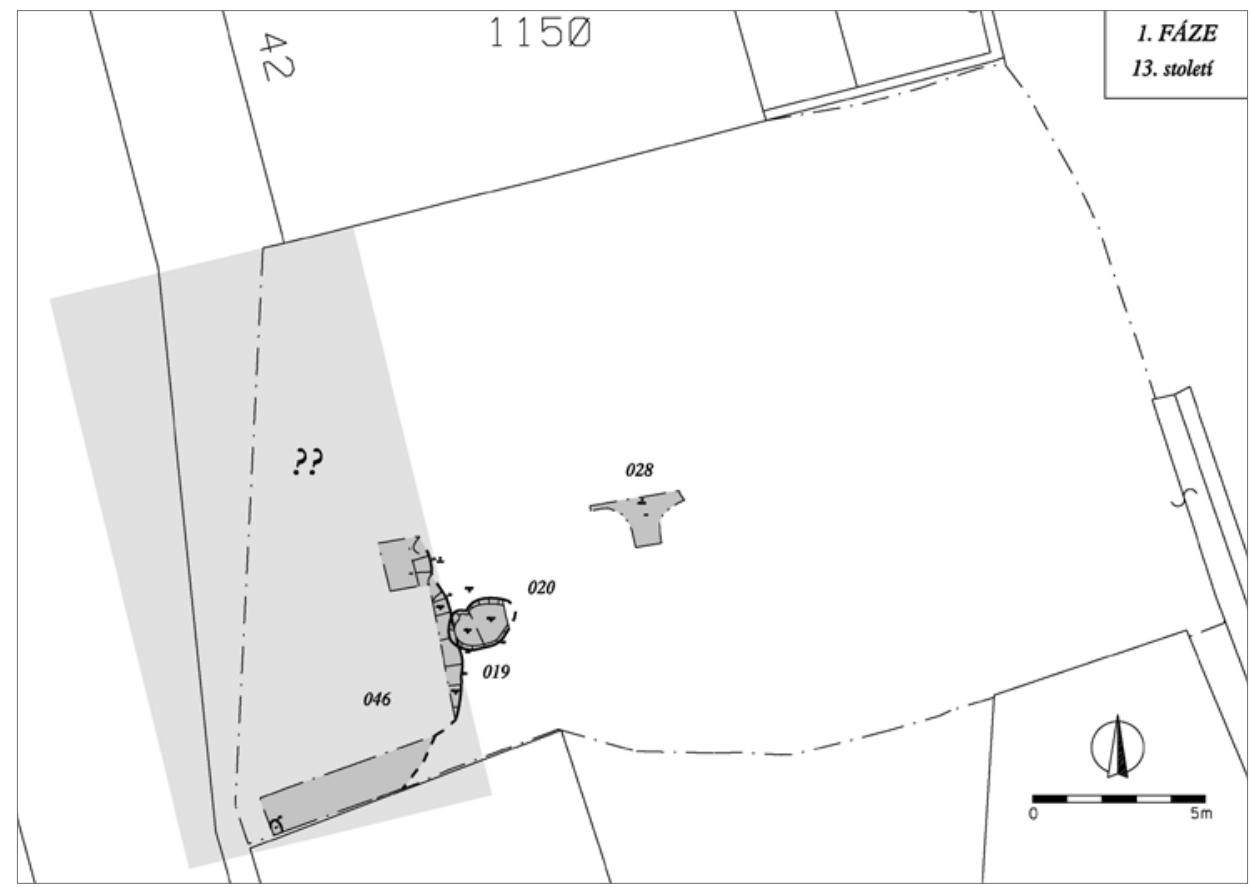

Obr. 5. První fáze stavebního vývoje. Rozsah zástavby neznámý (světle šedá). 046 - zahloubená část zřejmě dřevohliněné stavby; 019 a 020 - jámy neznámé funkce, mohou být mladší a byly by součástí interiéru stavby 026 (viz fáze 2 ); 028 - jáma neznámé funkce. Autor A. Zůbek.

Abb. 5. Erste Phase der baulichen Entwicklung. Umfang der Bebauung unbekannt (hellgrau). 046 - eingetiefter Teil eines offenbar Holz-Lehm-Baus; 019 a 020 - Gruben von unbekannter Funktion, sie könnten jüngeren Datums sein und waren Bestandteile des Interieurs von Bau 026 (siehe Phase 2); 028 - Grube von unbekannter Funktion. Autor A. Zủbek.

\section{2. fáze stavebního vývoje (13.-14. století)}

Došlo k zasypání stavby s. s. j. 046 a jámy 028. Stratigrafického nástupce představovala aktivita s. s. j. 026. Šlo o doklady po usazení svislých dřevěných konstrukčních prvků (kủlové a sloupové jamky) a pochozí úroveň (podlahové komunikační vrstvičky). Dokumentovaná situace nasvědčovala tomu, že tyto aktivity souvisely s jedinou stavbou. Její přesný půdorys neznáme. Odhadovat ho lze jako čtvercový či obdélný, rozměry přesahovaly hodnoty 15,6 a 15,3 m. Pochozí úroveň byla proti dochované úrovni středověkého terénu zahloubena o $0,3 \mathrm{~m}$. Původně však byla stavba velice pravděpodobně usazena do zářezu ve svahu. Východní stěna proto byla zřejmě poměrně výrazně zahloubena do terénu, opírala se o zářez svahu. Stavba by pokrývala v podstatě celou plochu tehdejší parcely. Předpokládat je nutné její vnitřní členění. Upozorňuje na to také přítomnost kůlových a sloupových jamek v interiéru stavby. Jeho rekonstrukce ovšem nebyla možná. Podél segmentů severní a východní stěny se táhly řady sloupových jam. Průměr sloupů v nich fixovaných lze odhadovat na $0,2 \mathrm{~m}$. Osazeny byly od sebe ve vzdálenosti $2,5 \mathrm{~m}$. Výkopy sloupových jam podél východní stěny byly výrazně větší. Tato skutečnost by mohla upozorňovat na nutnost větší stability, kterou vyžadoval případný tlak zaříznutého svahu, který východní stěna stavby zapírala. V př́ípadě s. j. 274, která byla zaznamenána v úrovni podlahy v jihozápadní části stavby, by mohlo jít o relikt otopného zařízení. Při severní stěně byl v interiéru stavby dokumentován blíže neurčený objekt s. s. j. 027. Na jeho někdejší konstrukci se podílely drobné svislé dřevěné konstrukční prvky kruhového průřezu o síle $4-7 \mathrm{~cm}$. Zůstalo po nich 17 jamek zahloubených do podlahy. Tvořily přibližně půlkruhovou linii o průměru $1 \mathrm{~m}$ táhnoucí se od sloupové jamky s. j. 521 ke sloupové jamce s. j. 522. Objekt snad souvisel s vybavením stavby. Je otázkou, zda by nemohlo jít o část konstrukce vstupu - schodiště? (obr. 6). 


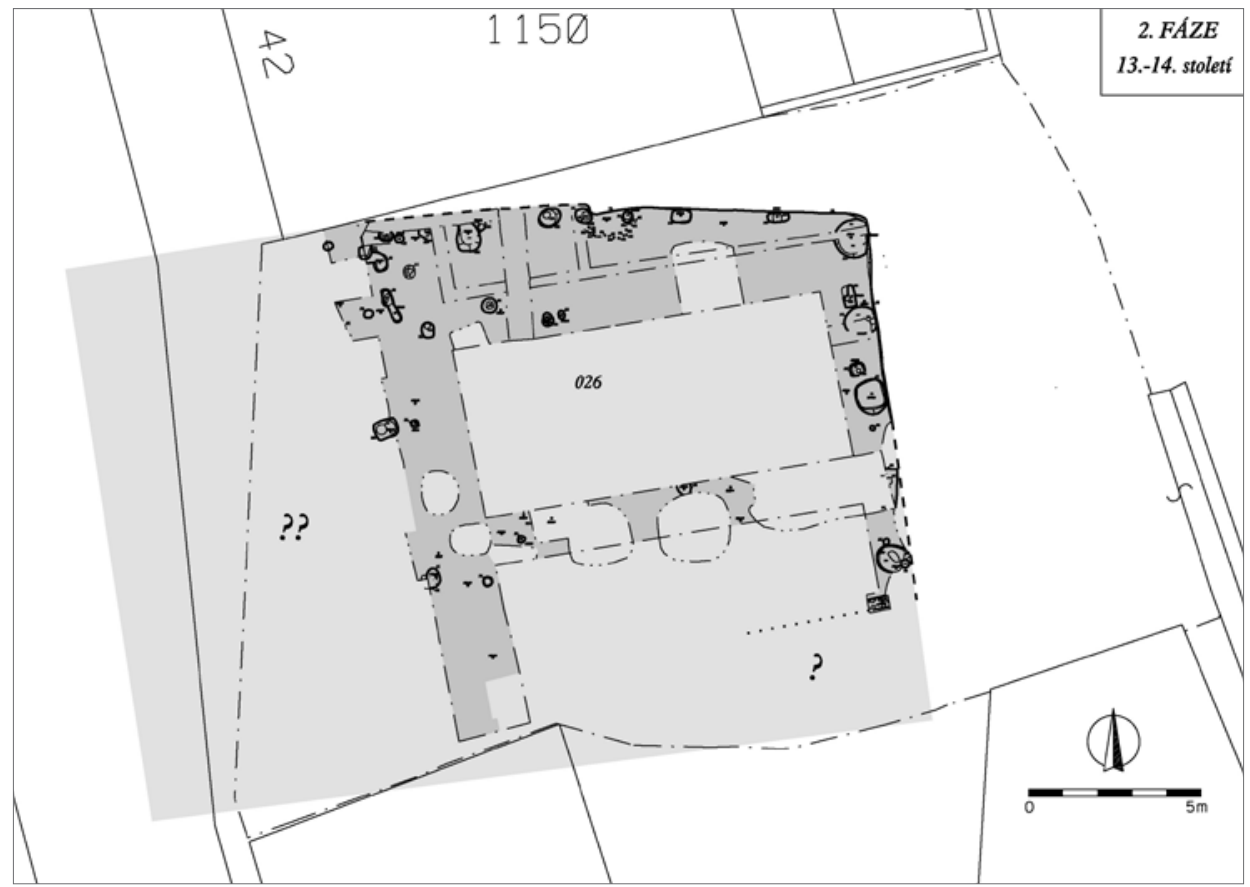

Obr. 6. Druhá fáze stavebního vývoje. 026 - zřejmě jedna stavba dřevohliněné konstrukce, usazená do zářezu ve svahu. Zářez pravděpodobně shodný s východní stěnou stavby. Přesný půdorys budovy zůstal neznámý. Autor A. Zủbek.

Abb. 6. Zweite Phase der baulichen Entwicklung. 026 - offenbar ein Bau mit Holz-Lehm-Konstruktion, gebettet in einen Schnitt im Hang. Der Schnitt ist wahrscheinlich mit der Ostwand des Baus identisch. Der genaue Grundriss des Gebäudes blieb unbekannt. Autor A. Zủbek.

\section{3. fáze stavebního vývoje (14.-15. století)}

Prostor stavby s. s. j. 026 byl zasypán. Jejím nástupcem se stala stavba s. s. j. 044. Jediným jejím dokladem byl ovšem pouze segment základového zdiva severní stěny. Je možné, že základ z kamenů ukládaných do hlíny byl utvářen zároveň se zasypáváním stavby s. s. j. 026. Jednoznačně prokázat tuto myšlenku však není možné. Konstrukce stavby byla zřejmě dřevohliněná. Podlahová úroveň stavby nebyla zachována. Neznáme ani rozsah a půdorys stavby. Stávala při uliční čáře. Není však jasné, zda byla vůči ní orientována okapově či štítově. V přední části parcely se podařilo zachytit v těsném sousedství dvě drobnější zásobní jámy (s. s. j. 010 a 011 ) a relikty dvou povrchových otopných zařízení (s. s. j. 003 a 018). Nebylo možné prokázat, zda jmenované objekty byly součástí interiéru stavby, či se nacházely pouze v její blízkosti. Z otopného zařízení s. s. j. 003 bylo zachyceno pouze jeho dno. Lze předpokládat navazující nadzemní konstrukci, ale nezachovaly se po ní žádné stopy. Povrch dna měl přibližně oválný půdorys o rozměrech 1,5 × 1,2 m. Konstrukce dna byla usazena do mělkého výkopu. Ten zčásti vznik1 modelací v nanesené sprašové hlíně, která se podílela také na výstavbě otopného zařízení. Na dně výkopu byla uložena vrstva, jejíž dominantní složkou byly valouny (ca 55 \%), dále železná struska (ca $30 \%$ ) a zlomky silnější tuhové keramiky (ca $15 \%$ ). Při východním okraji byla použita také dlaždice a tři velké zlomky prejzů. Usazovány (pojeny) byly do zmíněné sprašové hlíny, která je také překryla. Následovala uloženina, která sestávala ze dvou vrstev zlomků keramických nádob. Překryty byly opět sprašovou hlínou, která byla propálena do červenooranžové barvy. Popsané souvrství dosahovalo síly okolo $10 \mathrm{~cm}$. Z objektu s. s. j. 018 byl zachován pouze segment představovaný mělkým výkopem (,,prohlubni“), který byl vymodelován ve stejné sprašové hlíně jako dno otopného zařízení s. s. j. 003. Stěny i dno byly propáleny do červenooranžové 
barvy. Prohlubeň byla vyplněna popelem. Objekt se nacházel v těsné blízkosti jihovýchodního okraje otopného zařízení s. s. j. 003. Zřejmě spolu mohly souviset. V zadní části parcely se podařilo identifikovat několik objektů. Jejich stratigrafické vztahy se většinou nedaly určit, nemusely všechny existovat ve stejné době. Šlo o jámy neznámé funkce s. s. j. 012, 014, 031, 032 a 033. Dvě situace byly určeny jako do podloží vyhloubené sklípky, jeden poměrně malý (s. s. j. $021+022$ ) a druhý větší s chodbou raženou do východního svahu na hranici parcely (s. s. j. 005). Malý sklípek byl přístupný od jihu. Dokumentovaný výkop měl přibližně oválný půdorys o rozměrech $1,8 \times 1,4 \mathrm{~m}$. Výkop většího sklípku měl přibližně oválný půdorys o rozměrech $4 \times 3,4 \mathrm{~m}$. Nebyly dokumentovány žádné pozůstatky př́ípadné dřevěné konstrukce stěn. Při soudržnosti podložních vrstev zřejmě nemusely být žádné realizovány. $Z$ východní stěny do svahu ražená chodba měla šířku $1 \mathrm{~m}$ a délku větší než $2,5 \mathrm{~m}$. Výšku lze odhadovat na přibližně $2 \mathrm{~m}$. Na dně sklepa byla tenká komunikační (nášlapová) vrstvička. Otázka vstupu do sklepa nebyla jednoznačně vyřešena. Ražbou do svahu vnikla i prostora sklepa s. s. j. 004. Výkop vzniklý jeho destrukcí měl přibližně oválný půdorys o rozměrech $3,1 \times 2,7 \mathrm{~m}$. Vstup se nacházel na západní straně. O destrukce ražených sklepů zřejmě šlo také v případě situací s. s. j. 015 a 034 . Při budování jmenovaných objektů bylo zřejmě využiváno konfigurace přítomného svahu. Asi šlo o solitérní menší skladovací prostory, které se nemusely vázat na rozsáhlejší nadzemní stavbu. I když s nadzemní konstrukcí je u některých nutno počítat (obr. 7).

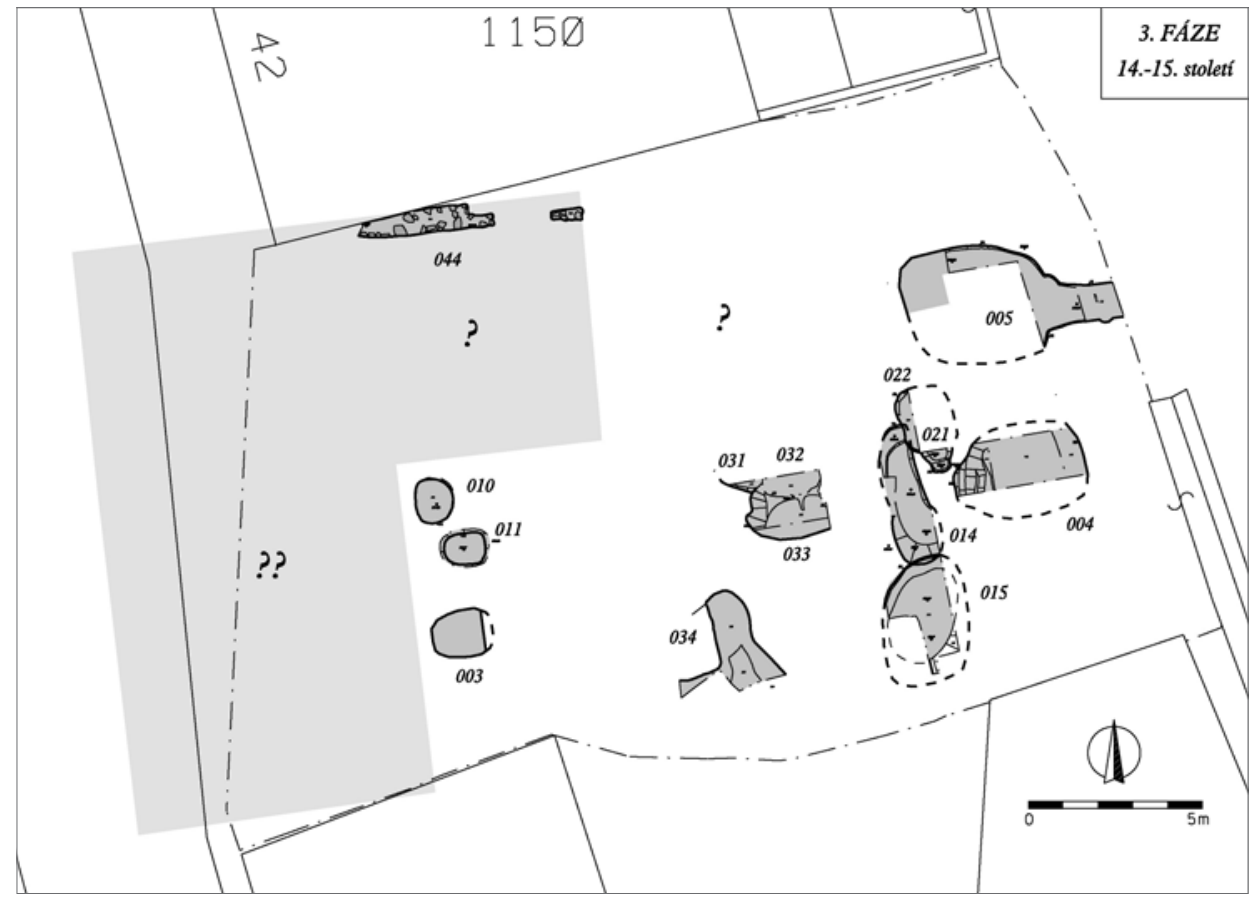

Obr. 7. Třetí fáze stavebního vývoje. Rozsah zástavby neznámý (světle šedá). 044 - základové zdivo (kameny na hlínu) severní stěny zřejmě dřevohliněné stavby; 004, 005, 021 + 022 - sklípky, 004 a chodba z 005 směrem k východu raženy do svahu; 015,034 - snad destrukce ražených sklepů/lochů; 014, 031-033 - jámy neznámé funkce; 010 a 011 - zásobnice; 003 - otopné zařízení. Autor A. Zůbek.

Abb. 7. Dritte Phase der baulichen Entwicklung. Umfang der Bebauung unbekannt (hellgrau). 044 - Fundamentmauerwerk (Steine auf Lehm) Nordwand eines offenbar Holz-Lehm-Baus; 004, 005, 021 + 022 - Keller, 004 und Gang von 005 in Richtung Osten in den Hang gegraben; 015, 034 - wahrscheinliche Zerstörungsschicht von gegrabenen Kellern/Löchern; 014, 031-033 - Gruben von unbekannter Funktion; 010 und 011 - Vorratsgruben; 003 - Heizanlage. Autor A. Zůbek. 


\section{4. fáze stavebního vývoje (15.-16. století)}

Při uliční čáře byly pro toto období zaznamenány segmenty zahloubené části stavby s. s. j. 045. Půdorys zůstal neznámý $(>10,5 \times>5 \mathrm{~m})$. Dokumentovány byly pouze segmenty horní partie východní stěny. Dno bylo zachyceno v severozápadním rohu zkoumané parcely. Hloubka od zachovaného povrchu středověkých aktivit činila přibližně $1 \mathrm{~m}$. Dno však bylo zřejmě víceúrovňové. Potvrzuje to skutečnost, že ve střední části nebylo dna ve stejné úrovni dosaženo. Konstrukce stěn zahloubené části stavby byla tvořena zřejmě dřevěnými prvky. Příslušná stavba stávala $\mathrm{v}$ čele parcely. Je otázkou, zda mohla být stratigraficky mladším doplňkem stavby s. s. j. 044, nebo vznikla až po jejím zániku. V jižním sousedství stavby byly zachyceny výkopové aktivity s. s. j. 036, 037, 038, 039 a 040. Většinu z nich lze interpretovat jako odpadní jímky. V zadní části parcely by mohly po jistou dobu ještě fungovat některé z objektů předchozí fáze (s. s. j. 005, 021+022). Nové situace zde nebyly zaznamenány. V tomto ohledu je poměrně zarážející přítomnost odpadních jímek v blízkosti uliční čáry. Pravděpodobnější by bylo jejich umístění do zadní (dvorní) části parcely. Je otázkou, zda je možné uvažovat o jejich příslušnosti k sousední parcele. Nebyla by orientována směrem k západu, ale k jihu (podél Kopečné ulice) a její zadní část s odpadními jímkami by sousedila s předmětnou parcelou (obr. 8).

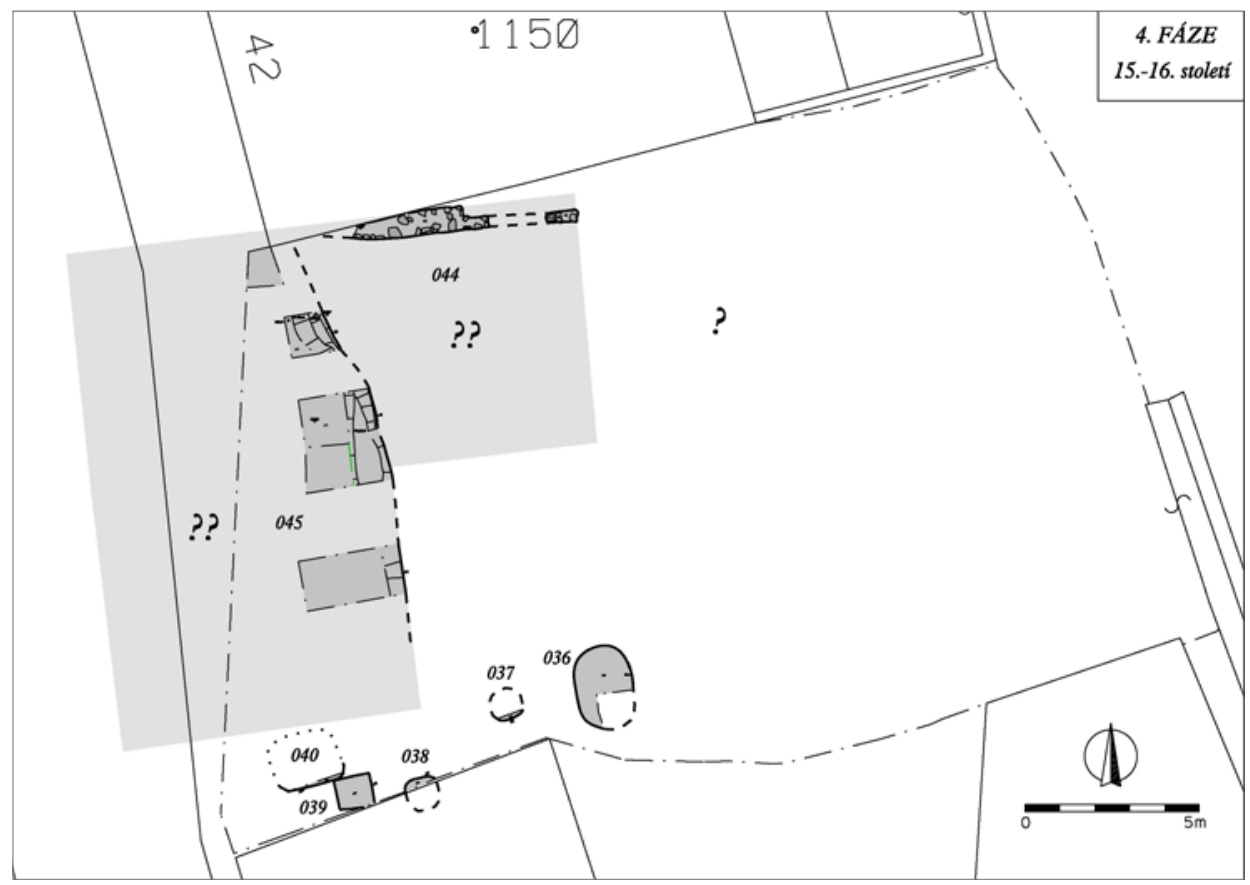

Obr. 8. Čtvrtá fáze stavebního vývoje. Rozsah zástavby neznámý (světle šedá). Stavba 044 již nemusí stát. 045 - zahloubená část zřejmě dřevohliněné stavby; 036-040 - odpadní jímky. Některé z objektů ze 3. fáze by mohly po jistou dobu ještě fungovat (005, $021+022)$. Autor A. Zůbek.

Abb. 8. Vierte Phase der baulichen Entwicklung. Umfang der Bebauung unbekannt (hellgrau). Bau 044 muss bereits nicht mehr stehen. 045 - eingetiefter Teil eines offenbar Holz-Lehm-Baus; 036-040 - Abwassergruben. Einige der Objekte aus der 3. Phase haben über einen gewissen Zeitraum noch in Funktion gewesen sein können (005, 021 + 022). Autor A. Zủbek.

\section{5. fáze stavebního vývoje (16.-17. století)}

Stavba s. s. j. 045 při uliční čáře byla zbourána, její suterénní část byla zasypána. V čele parcely byl zřejmě postaven nový dům s. s. j. 048. Zachyceny byly pouze segmenty základového zdiva západní stěny, jehož prvky byly pojeny hlínou. Přesný půdorys domu neznáme. Je otázkou, 
zda i nadzemní část byla tvořena zděnými konstrukcemi, nebo v ní byla využita dřevohliněná složka. Mohlo dojít i ke kombinaci obou technik. O další případné zástavbě nebyly získány žádné poznatky. S provozem zázemí parcely souvisely výkopové aktivity, dokumentované v její střední části s. s. j. 013, 016, 029, 030 a 049. Nejméně objekt s. s. j. 030 a snad i 013 lze považovat za odpadní jímky. Odpadní jímkou by snad mohl být i objekt zachycený starší sondou v severní části parcely (pracovně označen písmenem A). Dokumentované objekty s. s. j. 001 (zásobní jáma? / pec?), 023 (zahloubená pec) a 025 (destrukce do podloží raženého sklepa?) souvisely s vybavením zázemí sousední (severní) parcely (obr. 9).

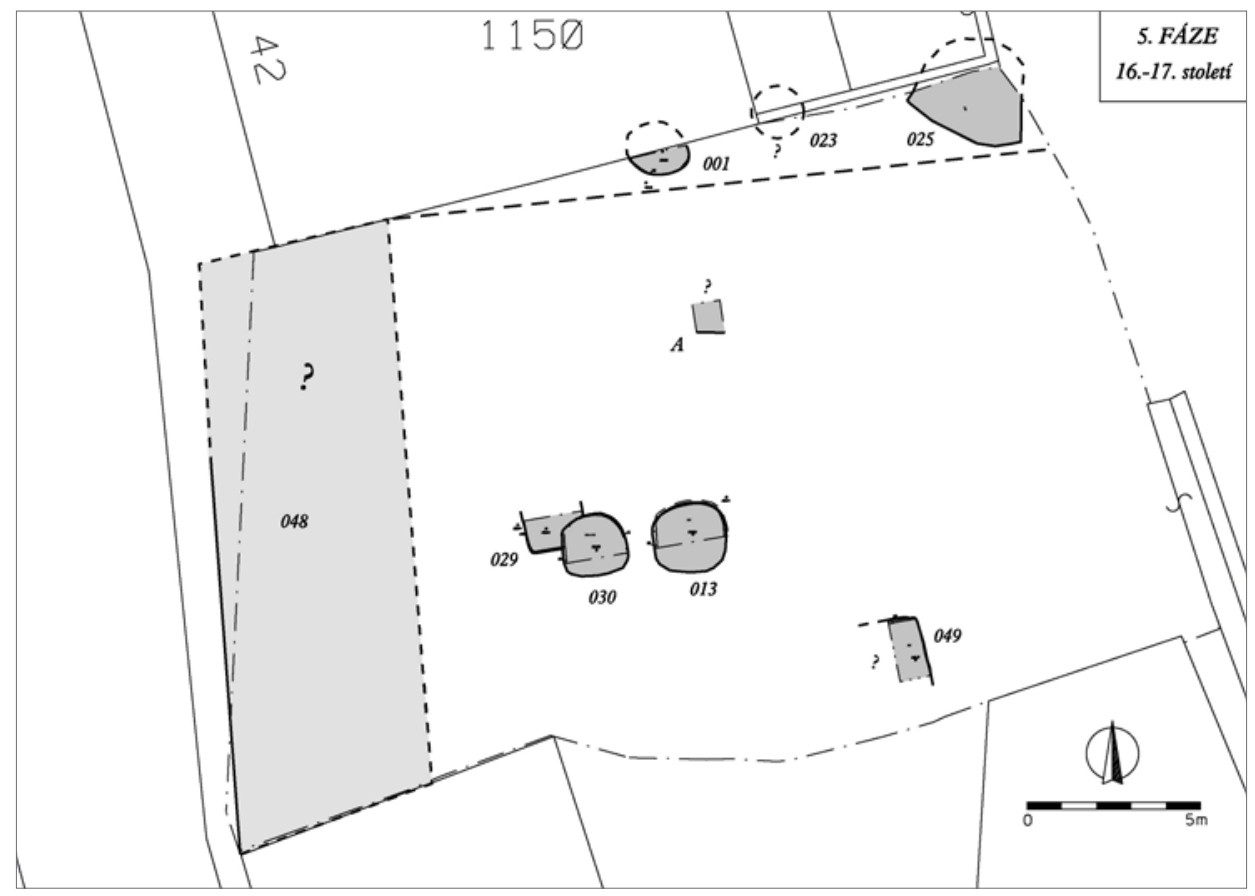

Obr. 9. Pátá fáze stavebního vývoje. Rozsah zástavby neznámý (zřejmě dům při ulici - 048). 013,030 a objekt A - odpadní jímky; 029 a 049 - jámy neznámé funkce. Objekty na sousední parcele: 001 - zásobní jáma? / pec?; 023 - zahloubená pec; 025 - destrukce do podloží raženého sklepa (?). Autor A. Zůbek.

Abb. 9. Fünfte Phase der baulichen Entwicklung. Umfang der Bebauung unbekannt (offenbar Haus an der Straße - 048). 013, 030 und Objekt A - Abwassergruben; 029 a 049 - Gruben von unbekannter Funktion. Objekte auf der Nachbarparzelle: 001 - Vorratsgrube? / Herd?; 023 - eingetiefter Herd; 025 - Zerstörungsschicht eines in den Untergrund gegrabenen Kellers (?). Autor A. Zůbek.

\section{6. fáze stavebního vývoje (18.-19. století)}

Zástavbu parcely lze rekonstruovat s přihlédnutím k existujícím plánům z konce 18. a 19. století (viz obr 11). Vytvářela podél hranice parcely přibližně tvar písmene U, otevřeného směrem $\mathrm{k}$ jihu. Z písemných pramenů víme, že parcela tvořila jeden majetkový celek s parcelou dnešního domu Kopečná 38 (viz oddíl 1 Historický úvod). V čele zkoumané parcely stával při uliční čáře dům. Je otázkou, zda stavba s. s. j. 048 začleněná již do předchozího období nevznikla až nyní a měla svého výzkumem neidentifikovaného předchůdce, nebo zda vznikla skutečně již tehdy a přežila (s možnými úpravami) i do tohoto období. Severní křídlo zástavby tvořila stavba s. s. j. 047. Zachovány zůstaly pouze segmenty základových zdiv pojených maltou. Podlahová úroveň nebyla př́ítomna. Stavba nebyla podsklepena. O nadzemní podobě nevíme nic. Po východním křídle se nezachovaly žádné stopy. Na dvoře byla zřízena studna s. s. j. 002, objekt s. s. j. 035 lze označit za odpadní jímku (obr. 10). 


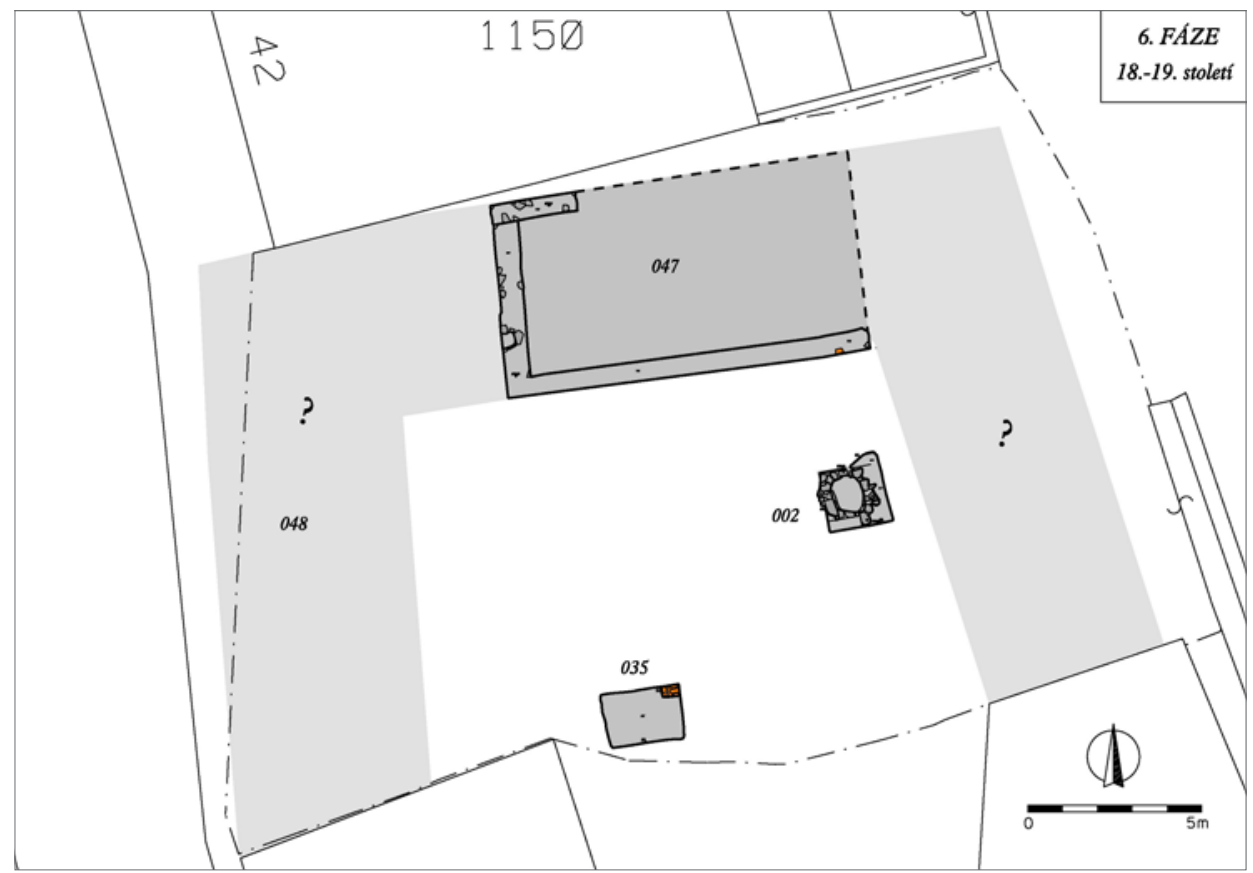

Obr. 10. Šestá fáze stavebního vývoje. 047 - severní kř́ídlo zástavby se základy zděnými na maltu; 002 - studna; 035 - odpadní jímka. Autor A. Zůbek.

Abb. 10. Sechste Phase der baulichen Entwicklung. 047 - Nordflügel der Bebauung mit auf Mörtel gemauerten Fundamenten; 002 - Brunnen; 035 - Abwassergrube. Autor A. Zůbek.

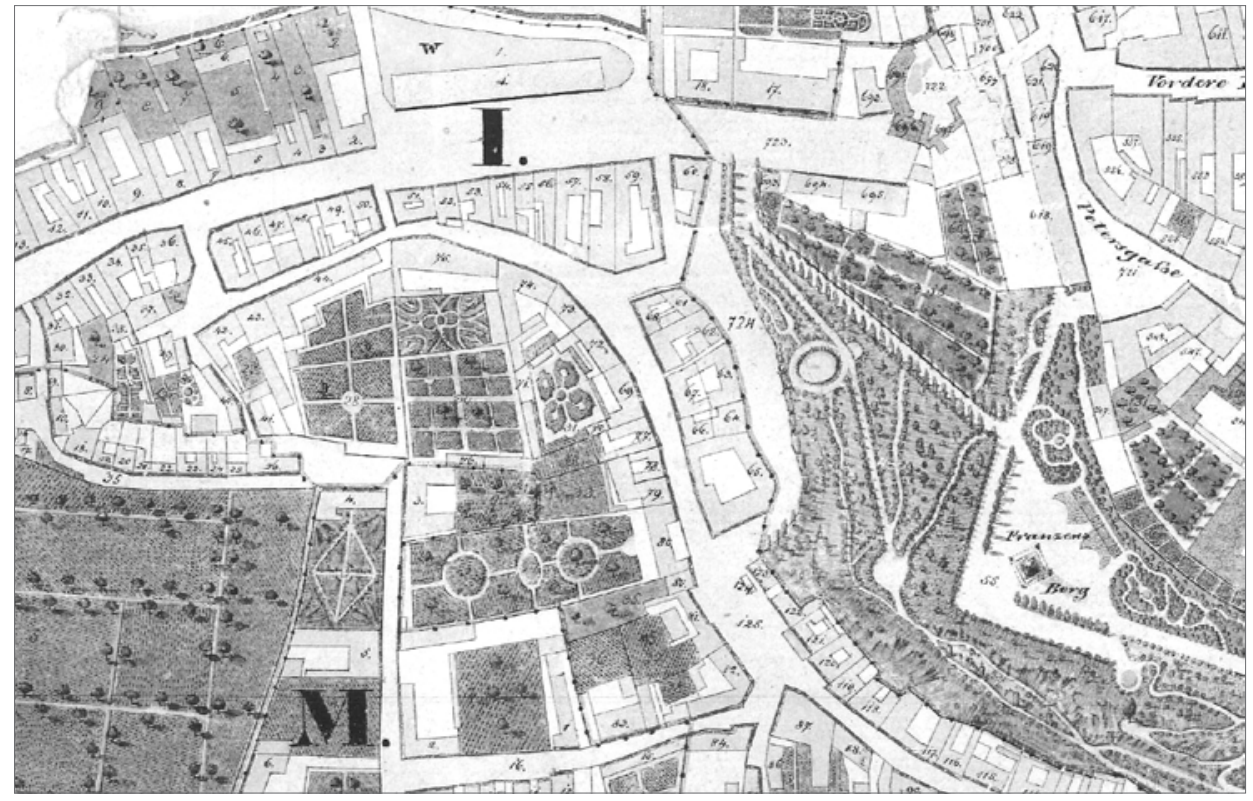

Obr. 11. Výřez plánu z roku 1825. Zdroj Ústřední archiv zeměměřičství a katastru B2-a-4-M2487. Dủm, jehož součástí je dnešní parcela č. 1149/3, je označen číslem 65 .

Abb. 11. Ausschnitt eines Planes aus dem Jahr 1825. Quelle Zentralarchiv Landesvermessung und Kataster B2-a-4-M2487. Das Haus, dessen Teil heute Parzelle Nr. 1149/3 ist, wurde mit der Ziffer 65 gekennzeichnet. 
Při jižní hranici parcely se při zemních pracích narazilo na segment sklepa, který se nachází pod dvorkem domu Kopečná 38. Má obdélný půdorys o rozměrech 5,6 × 4,2 m (orientován je severozápad-jihovýchod). Maximální vnitřní výška činí 2,15 m. Vyzděn je z cihelného zdiva, vybaven valenou klenbou. Zřejmě později byla položena podlaha z cihel. V jižní stěně se nachází vstup do dalších prostor, které podle staré plánové dokumentace zasahují zčásti pod stávající dům. V době výzkumu byl vstup zasypán (obr. 13).

\section{Archeologické poznatky $k$ uličce U studánky}

Na profilu při východní hranici staveniště se podařilo dokumentovat terénní podmínky v prostoru někdejší uličky, která procházela ve svahu podél východní hranice domovního bloku 61. V 19. století se této uličce ř́ikalo Pod Františkovem či U studánky (Flodrová 1997, 230). Povrch geologického podloží zde byl „seříznut“ a mírně klesal směrem k jihovýchodu. Během novověku se na něm utvořilo 1 až 1,5 m silné souvrství. Složeno bylo z navážek, jejichž účelem bylo zřejmě navýšit úroveň cesty, a komunikačních úprav tvořících její povrch. Dvě úpravy byly tvořeny štěrkem, třetí, nejmladší představovalo dláždění. Následovalo zvýšení terénu ve 20. století. Že zde docházelo také $\mathrm{k}$ jiným než komunikačním procesům a zvyšování povrchu cesty, svědčí výkopy dvou jam neznámé funkce.

\section{Shrnutí}

\section{Vývoj zástavby}

Z popisu jednotlivých stavebních fází parcely vyplývá, že její osídlení prošlo v průběhu doby poměrně rozmanitým vývojem. V nejstarším období máme doloženu zástavbu v čele parcely při dnešní Kopečné ulici. Uvažovat lze o obytném domě se zahloubenou partií, který stál na úpatí svahu. O př́padné dvorní části domu nevíme v podstatě nic. V prvotním období, jestli vůbec existovala, nemusela být utvořena zářezem do terénu. Nástupcem domu byla poměrně rozsáhlá stavba, která byla svou východní stěnou přisazena $\mathrm{k}$ seříznutí terénu. Zázemí by se muselo nacházet ve zvýšené úrovni zachovalé části svahu. Případně je nutné uvažovat o přnináležitosti pozemku dnes samostatných parcel v jižním či severním sousedství. Pravděpodobnější se jeví varianta, že stavba představovala samostatný objekt. V následném období se zástavba vázala opět na čelo parcely. Dům však zasahoval již méně do její hloubky. Otázkou je ovšem někdejší existence dvorních křídel, popřípadě dalších staveb, po nichž se nám nemusely zachovat žádné stopy. Rozsah parcely se nejméně v severovýchodní partii zvětšil posunutím zářezu do svahu. Zázemí bylo využíváno k budování sklípků. Z dalších objektů bylo dokumentováno několik jam, jejichž funkce nebyla určena. Teprve se sklonkem středověku a počátkem novověku se objevily odpadní jímky. Zaznamenány však byly nejprve v sousedství domu při čele parcely v prostoru, kde byla původně situována zahloubená část nejstarší stavby. Tato situace by narušovala „klasické" schéma historických parcel, v němž jsou odpadní jímky většinou součástí vybavení dvorních (zadních) částí domů. Zřejmě je nutné uvažovat o tom, že dokumentované odpadní jímky souvisely se sousední parcelou, která by nebyla orientována směrem k západu, ale k jihu (podél Kopečné ulice). Pro mladší období byly jímky doloženy již ve dvorní části. Dům stál okapově orientován při ulici. Postupně docházelo k utváření severního a východního křídla, až zástavba parcely vytvořila tvar písmene $\mathrm{U}$, otevřeného k jihu, tak jak ji zobrazují plány z konce 18. a počátku 19. století.

Důvodem k jednotlivým přestavbám zástavby byly zřejmě účelové potřeby majitelů parcely. Nebyly zaznamenány žádné doklady požáru, který by pozemek postihl, a vynutil si tak novou výstavbu. Zcela vyloučit ovšem tuto možnost nelze. Do plánů obyvatel mohly výrazně zasáhnout válečné události.

V této souvislosti je nutné se zastavit u skutečnosti, že na vyobrazeních z druhé poloviny 17. století není osídlení pod Petrovem zaneseno (viz oddíl 1 Historický úvod). Zachycují švéd- 
ské obléhání Brna v roce 1645, ale nejsou na nich patrné ani relikty po zplanýrování zástavby, které provedli na předměstích obránci záměrně, popř́padě ho dokonali obléhatelé. V ostatních osadách jsou zbytky zástavby většinou jasně vyznačeny (viz obr. 1). Je možné, že zplanýrování osídlení pod Petrovem proběhlo tak dokonale, že po zástavbě nezůstaly stopy. Vyloučit nelze ani opomenutí autorů vyobrazení. Nebo bychom museli předpokládat, že na jistou dobu zde muselo osídlení zaniknout. Otázkou by byl důvod tohoto zániku a délka období, po kterou zůstal prostor nezastavěn. Na základě archeologických poznatků získaných výzkumem parcely č. 1149/3 bychom museli hiát v osídlení usadit do období 5. fáze stavebního vývoje. Jeho počátek by mohl být spatřován ve zplanýrování stavby s. s. j. 045 a konec ve výstavbě domu s. s. j. 048 . Archeologický materiál by teoreticky dovolil připustit neosídlení parcely v období 17. a první poloviny 18. století. Snad se zatím jako nejpravděpodobnější jeví varianta, že ke zplanýrování zástavby došlo v souvislosti s válečnými událostmi během třicetileté války (možná již během ohrožení Brna v roce 1643). Je otázkou, zda bylo osídlení obnoveno bezprostředně, nebo až po jisté době. Situace bude muset být konfrontována s výsledky ostatních výzkumů a podrobnější rešerší archivních pramenů.

\section{Hranice parcely}

V období středověku se parcela postupně zvětšovala. Její pozemek se stále více zařezával východním směrem do svahu terénu. $V$ průběhu doby zřejmě nebyly striktně dodržovány ani hranice vůči sousedním pozemkům. Docházet mohlo k drobnějším posunům či vypořádáním mezi sousedy. Tímto způsobem by se dala vysvětlit zmíněná prítomnost odpadních jímek v čele parcely v období 4 . fáze stavebního vývoje. Rovněž od delší osy dnešní parcely byla ta historická odchýlena o sedm a v období středověku možná až o 14 stupňů. Tímto posunem se na stávající parcele ocitly objekty někdejšího severního souseda (viz 5. fáze stavebního vývoje). Písemné prameny dokládají, že od druhé poloviny 18. století tvořila parcela společně se sousední jižní parcelou jeden majetkový celek. Je otázkou, zda tomu tak mohlo být i ve starším období. Zkoumaná situace snad naznačuje spíše existenci pozemku jako samostatného subjektu.

\section{Nakládání s odpadem}

Zmínkou o odpadních jímkách se dostáváme k otázce, jakým způsobem obyvatelé parcely nakládali s běžným odpadem domácnosti. Řešení prostř̌ednictvím „klasických“ odpadních jímek přišlo až na sklonku středověku a v období novověku. Do té doby nebyly na parcele jednoznačně doloženy. Nejstarší jímky lze zařadit dle keramického materiálu do druhé poloviny 15. a počátku 16. století. Jde však o komentované př́ípady v blízkosti uliční čáry, které nemusely k parcele náležet. Jednoznačně s ní souvisejí až odpadní jímky z 5. fáze stavebního vývoje. Výplně s. s. j. 013 a 030 poskytly keramický materiál datovaný do 17. století, objekt A obsahoval keramiku 17.-18. století. Pro deponování odpadu mohly být ve 3 . stavební fázi druhotně využity zaznamenané jámy neznámé funkce. Primárně snad mohl být odpad ukládán v nedalekém okolí osady, jejíž struktura nebyla svázána a limitována tak jako vnitřní město.

\section{Zdroj vody}

Obdobná je problematika př́istupu obyvatel parcely k pitné a užitkové vodě. Vlastní zdroj vody je doložen až v období 18. a 19. století. Představovala ho studna ve dvorní části. Zkoumaná situace naznačovala, že zřejmě neměla starší předchůdkyni. Zcela vyloučit to ovšem nelze. Do té doby mohl jako zdroj vody sloužit nějaký pramen v blízkém sousedství. Historicky znám je pramen na Františkově (Fons salutis). Dnes se jeho vyústění nachází v blízkosti parcely ca $40 \mathrm{~m}$ ve svahu východním směrem. Jeho využívání již v 16. století doložil archeologický výzkum z roku 2010 (Dejmal a kol. 2011, 125). Je možné, že voda z tohoto pramene mohla odtékat po svahu právě prostorem osady, jejíž součástí byla předmětná parcela. Vzdálenost ke Svrateckému 
náhonu činila $140 \mathrm{~m}$. Otázkou je existence veřejné studny sloužící pro potřeby více domů. Jednu z nich při nedalekém domě Kopečná 274/36 i pro mladší období dokládá fotografie z roku 1907 (Archiv města Brna, Kunzfeld XIIIa 8).

\section{Podoba zástavby}

K přesné podobě zástavby se není možné jasnějším způsobem vyjádřit. Nelze rekonstruovat ani původní rozsah a půdorys jednotlivých domů a staveb. Víme, že některé ze středověkých domů měly zahloubenou část, př́ípadně byly vybaveny přímo suterénem. Novověké sklepy chyběly. Bližší informace o dispozici a vybavení domů nebyly získány. Stavba s. s. j. 026 byla zřejmě v jihozápadní části v úrovni podlahy vybavena otopným zařízením. Jeho stopy však byly velmi nepatrné. Přibližně na stejném místě byla doložena existence dvou povrchových otopných zařízení i v následující 3 . fázi stavebního vývoje. Nebylo však možné jasně prokázat, zda jmenované objekty byly součástí interiéru stavby, či se nacházely pouze v její blízkosti (pod př́střeškem?). Neznámá zůstala rovněž přesná funkce zařízení. Ze zásypů novověkých výkopových aktivit bylo získáno několik zlomků kamnových kachlů. Je ovšem otázkou, zda na jejich základě můžeme uvažovat o vybavení tehdejšího domu kamny.

Konstrukčním materiálem středověkých staveb byly dřevo a hlína. U stavby s. s. j. 044 byl zaregistrován jednoduchý základ z kamenů pojených hlínou. Dřevěné prvky byly zřejmě nositelem vlastní konstrukce, hlína (v podobě mazanice) sloužila jako doplňkový materiál. Vlastní dřevěné prvky se nedochovaly, jen průměry některých z nich lze odhadovat z rozměrů zachovalých kůlových a sloupových jamek. Poznatky nebylo možné rozššririt ani na základě studia zlomků vypálené mazanice, na nichž je za příznivých podmínek možné pozorovat informační odraz dřevěných konstrukcí. Žádná ze zachycených staveb totiž nezanikla požárem. Přesné technologické řešení staveb zůstává neznámé.

S obdobím novověku přicházejí doklady zděných konstrukcí. V prrípadě stavby s. s. j. 048 ovšem šlo pouze o segmenty základového zdiva západní stěny. Tvořeno bylo kameny a cihlami a jejich zlomky pojenými hlínou. První na maltu zděné konstrukce představovala až základová zdiva severního křídla (s. s. j. 047). Všechny ostatní doklady zástavby z období novověku až 20. století zmizely takřka beze stopy.

\section{Obyvatelé parcely}

Je možné prohlásit, že osídlení parcely bylo součástí osady, jejíž obyvatele známé středověké prameny označují jako „chudé pod Puhlíkem“. Na základě získaných archeologických pramenů není možné usuzovat na to, co bylo zdrojem obživy majitelů parcely. Dokumentované situace nenapověděly téměř nic a mnoho informací nepřinesl ani získaný mobiliář. Zda by v případě otopného zařízení s. s. j. 003 mohlo jít o výrobní objekt, je pouze hypotetická otázka (jeho popis viz oddíl 3. fáze stavebního vývoje). Nálezové kolekce byly poměrně nevýrazné a o životě zdejších lidí mnoho nevypovídaly. Většinou byly získány pouze fragmenty běžné kuchyňské keramiky a zvířecí kosti. Osteologická analýza dosud nebyla provedena. Usuzovat na základě zlomku podkovy ve výplni stavby s. s. j. 026 na př́ítomnost koně jednoznačně nelze. Ve stejné vrstvě byl nalezen také oboustranný kostěný hřeben (obr. 12). Mnoho nevypovídají ani nálezy tří středověkých mincí. Dvě zatím nebyly určeny, protože dostatečně nepokročil proces jejich

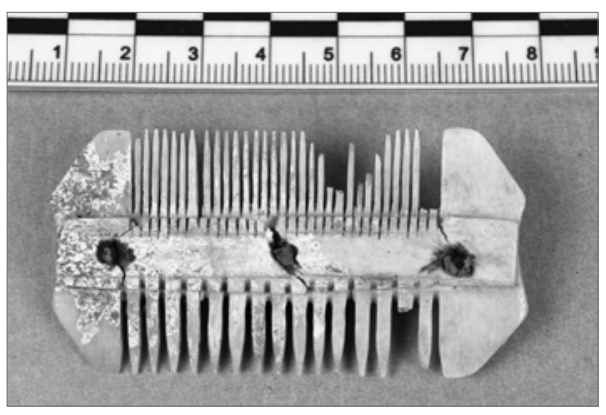

Obr. 12. Kostěný hřeben z výplně stavby 026 . Zdroj fotoarchiv Archaia Brno, o. p. s.

Abb. 12. Kamm aus Bein aus der Verfüllung von Bau 026. Quelle Fotoarchiv Archaia Brno, o. p.s. 


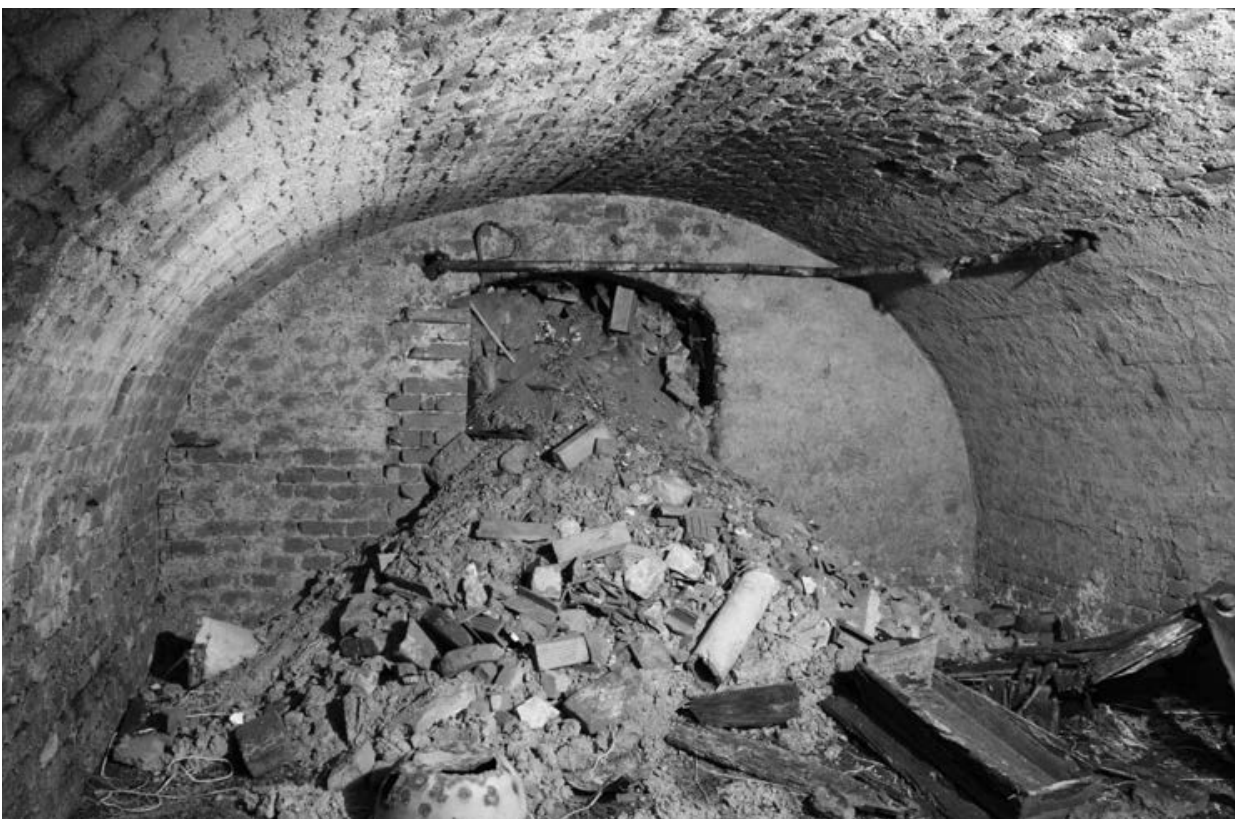

Obr. 13. Pohled od severu do sklepa pod dvorkem domu Kopečná č. 319/38. Zdroj fotoarchiv Archaia Brno, o. p. s. - foto č. 48-2014.

Abb. 13. Blick von Norden in den Keller unter dem Hof des Hauses Kopečná-Str. Nr. 319/38. Quelle Fotoarchiv Archaia Brno, o. p. s. - Foto Nr. 48-2014.

konzervace, která by zajistila „čitelnost“. V jednom případě jde o pražský groš Jana Lucemburského (určení provedl Mgr. Kamil Smíšek). Nalezen byl společně s další mincí ve výplni zásobní jámy s. s. j. 010, která byla zařazena do 3. fáze stavebního vývoje. Poslední mince byla součástí výplně jámy neznámé funkce s. s. j. 014 ze stejné fáze. Zaměstnání majitelů domu známe až pro 19. století. Jedním z nich byl např́klad jirchářský mistr, další dva následovníci provozovali v domě pekařskou živnost.

\section{Závěr}

Archeologický výzkum parcely č. 1149/3 přinesl ve svých výsledcích důležité informace k poznání nejstarší historie Kopečné ulice. Vedle ostatních archeologických výzkumů se stal dalším základním kamenem řady, která vede k objasnění topografického vývoje této části města. Potvrzuje se, jak důležité je sledovat systematicky všechny zemní zásahy spojené s rozličnými stavebními počiny, realizované na předmětném území. Díky nim se postupně skládá mozaika poznání jeho historického vývoje. Dnes můžeme prohlásit, že v daném prostoru dosavadní výzkumy jasně potvrdily přítomnost středověkého osídlení, a to od počátků města ve 13. století. Vnikalo zřejmě kolem komunikace procházející od Pekařské ulice pod skalním ostrohem Petrova směrem ke Svrateckému náhonu (dnes Kopečná ulice). Při této komunikaci na úpatí svahu byla situována také parcela č. 1149/3. Výzkum doložil její osídlení již od 13. století. Nelze však vyloučit, že daný prostor byl obydlen ještě před založením města. Výsledky, které výzkum přinesl, dovolují sledovat alespoň do jisté míry proměny zástavby parcely po celé období její existence. Stavební vývoj je možné rozčlenit do šesti základních fází. Jde v podstatě o první př́ípad parcely na historickém předměstí Brna, jejíž historii bylo možné tímto uceleným způsobem sledovat po celé období vývoje od 13. až do 20. století. Na ostatních místech většinou není situace tak př́ihodná. Často byly archeologicky zkoumány jen segmenty parcel nebo byl archeologický terén silně poničen, existence některých parcel nebyla tak dlouhá. Parcela č. 1149/3 nese určitá 
specifika. Je součástí jednoho typu osídlení, které vzniklo v rámci předměstské struktury středověkého města. Písemnými prameny je označováno jako „chudí pod Puhlíkem“. Do charakteru zástavby parcely se určitě promítala také konfigurace terénu, do které byla usazena. Poloha na úpatí svahu zdejší obyvatele zřejmě nutila k úpravám terénu a mohla vybízet k výstavbě specifických objektů, které na lokalitách s odlišnou terénní konfigurací vybudovat nelze (např. do svahu vkopané sklípky, chodby atd.). Př́itomné archeologické situace tak představují odraz života, který na parcele této kategorie probíhal. Seznámit veřejnost se získanými poznatky, a tím umožnit případné srovnání s podobným typem lokality bylo prvotním impulzem k publikování této stati.

\section{Prameny a literatura}

Archiv města Brna, fond A 1/3, rkp. č. 1912, fol. 199.

Archiv města Brna, fond A 1/3, rkp. č. 1914, fol. 11n.

Archiv města Brna, fond A 1/33, inv. č. 718, kart. 175.

Archiv města Brna, Kunzfeld XIIIa 8.

ČERNÁ, L.-ZƯBEK, A., 2015: Nálezová zpráva o provedení záchranného archeologického výzkumu při stavbě „Bytový dům Kopečná-Studánka“ k.ú. Staré Brno, p.č. 1149/3. Nálezová zpráva č. 16/14 ulož. $\mathrm{v}$ archivu společnosti Archaia Brno, o. p. s.

DEJMAL, M. a kol., 2011: DEJMAL, M.-HOLUB, P.-KOLAŘÍK, V.-MERTA, D.-PEŠKA, M.-SEDLÁČKOVÁ, L.-ZBRANEK, H.-ZŮBEK, A. a kol., Brno (okr. Brno-město), PV 52, 106-133.

FLODROVÁ, M., 1997: Brněnské ulice a vývoj jejich názvů od 13. století po dnešek. Brno.

FLODROVÁ, M.-MÜLLER, Z., 2007: Staré Brno. Vyprávění o minulosti nejstarší části města Brna. Brno. JAN, L., ed., 2013: Dějiny Brna 2. Středověké město. Brno.

KUČA, K., 2000: Brno. Vývoj města, předměstí a připojených vesnic. Praha - Brno.

MERIAN, M., 1650: Topographia Bohemiae, Moraviae et Silesiae, das ist, Beschreibung und eigentliche Abbildung der Vornehmsten und bekandtesten Stätte und Plätze in dem Königreich Boheim und einverleibten Ländern, Mähren und Schlesien. Frankfurt. Použit exemplář uložený v Moravské zemské knihovně v Brně pod signaturou ST3-0035.392.

PROCHÁZKA, R., 2000: Zrod středověkého města na př́ikladu Brna (k otázce odrazu společenské změny $\mathrm{v}$ archeologických pramenech), Mediaevalia archaeologica 2, 7-158.

PROCHÁZKA, R.-KOLAŘíK, V.-ZŮBEK, A., 2013: Předměstí. In: Dějiny Brna 2. Středověké město (Jan, L., ed.), 568-600. Brno.

RELATIONE: Relatione dell assedio di Bruna e de la fortezza di Spilberg. Vienna 1672. Použit exemplář uložený v Moravské zemské knihovně v Brně pod signaturou ST2-0018.958.

VIČAR, O., 1966: Místopis Brna ve 14. století (Předměstí), BMD 8, 226-273.

ZAPLETALOVÁ, D., 2005: Zpráva o záchranném archeologickém výzkumu. Brno, blok 61, č. akce A62/2004). Nálezová zpráva č. 18/05 ulož. v archivu společnosti Archaia Brno, o. p. s.

\section{Zusammenfassung}

\section{Die historische Entwicklung der Bebauung von Parzelle Nr. 1149/3 an der Brünner Straße} Kopečná

Die archäologische Grabung auf Parzelle Nr. 1149/3 lieferte wichtige Erkenntnisse zur ältesten Geschichte der Straße Kopečná. Neben anderen archäologischen Grabungen wurde sie zum Grundstein einer Grabungsreihe, die Aufschluss über die topographische Entwicklung dieses Stadtteils gibt. Dadurch wird bestätigt, wie wichtig es ist, alle im Erdreich erfolgten Eingriffe zu untersuchen, die mit den verschiedensten im betreffenden Raum erfolgten Bauaktivitäten verbunden sind. Anhand von ihnen kann das Mosaik der historischen Entwicklung der Parzelle Steinchen für Steinchen vervollständigt werden. Heute können wir behaupten, dass durch die bisherigen Grabungen klar bestätigt wurde, dass im Mittelalter im besagten Raum eine Besiedelung stattgefunden hat, und zwar seit den Anfängen der Stadt im 13. Jahrhundert. Sie war offenbar im Bereich des Straßenverlaufs vorgedrungen, der von der Pekařská-Str. unterhalb der 
Felsenzunge des Petersberges zum Svratka-Mühlbach (heute Kopečna-Str.) verlief. An diesem Straßenverlauf am Fuß des Hangs lag auch die Parzelle Nr. 1149/3. Durch die Grabung wurde belegt, dass sie bereits ab dem 13. Jahrhundert besiedelt wurde. Es kann jedoch nicht ausgeschlossen werden, dass der betreffende Raum nicht bereits früher, noch vor der Stadtgründung bewohnt gewesen war. Die durch die Grabung erzielten Ergebnisse erlauben es zumindest, bis zu einem gewissen Grad die Veränderungen in der Bebauung nachzuzeichnen, welche die Parzelle während ihrer gesamten Existenz durchgemacht hat. Die bauliche Entwicklung kann in sechs Grundphasen unterteilt werden. Im Grunde genommen handelt es sich hier um den ersten Fall einer Parzelle in der historischen Vorstadt Brünns, deren Geschichte auf eine solche in sich geschlossene Art und Weise über den gesamten Entwicklungszeitraum vom 13. bis zum 20. Jahrhundert nachgezeichnet werden konnte. An den übrigen Orten ist die Situation meist nicht so günstig. Häufig wurden nur Parzellensegmente archäologisch untersucht oder das archäologische Gelände war stark zerstört, einige Parzellen haben nicht so lange existiert. Die Parzelle Nr. 1149/3 hat gewisse Besonderheiten vorzuweisen. Sie ist Bestandteil eines Besiedelungstyps, der im Rahmen der Vorstadtstruktur der mittelalterlichen Stadt entstanden war. Die Bewohner der Vorstadtsiedlung werden in den schriftlichen Quellen als „die Armen unter dem Purzelbüchel" bezeichnet. In den Bebauungscharakter der Parzelle hat sich sicherlich auch die Konfiguration des Geländes niedergeschlagen, in der sie angesiedelt war. Die Lage am Fuß des Hanges hatte die dortigen Bewohner offenbar dazu gezwungen, das Gelände entsprechend herzurichten und konnte dazu aufgefordert haben, spezielle Objekte zu errichten, die an Standorten mit einer anderen Geländekonfiguration nicht gebaut werden konnten (z.B. in den Hang gegrabene Keller, Gänge usw.). Die vorhandene archäologische Situation spiegelt somit das Leben wider, wie es sich auf einer Parzelle von einer solchen Kategorie abgespielt hat.

Mgr. Antonín Zůbek, Ph.D., Archaia Brno, o. p. s., Bezručova 15, 60200 Brno, Česká republika, azubek@archaiabrno.cz 